\title{
Prairie Fires Menaced Settlers
}

\author{
By N. TJernageL
}

[This is the concluding article of a remarkably fine series upon pioneer experiences in Story county, Iowa, and surrounding area, by Mr. N. Tjernagel of the Follinglo Farm, Story City, which have appeared in the AnNaLs the past two years. They have ably and faithfully depicted the early settlements of those who endured the privations and dangers of Iowa pioneer life, and were written by a man who is still engaged in the practical tasks of farm living, speaking from the heart of an actual participant. These true-to-life experiences have covered practically every phase of the lives of the early settlers, and the occasional thrilling incidents have not been over-drawn. The articles have historical value and being authentic as to both events and individuals form a glowing composite picture of the struggles and achievements of our people in the early days of the Hawkeye state. Mr. Tjernagel's ability as a descriptive writer is firmly established and his supreme desire realized to place in imperishable form for preservation this epic upon the passing of the prairie.-Editor.]

\section{Blazes From the Northwest}

In talking of pioneer times James Sowers always spoke interestingly concerning the prairie fires he had witnessed in his youth. The greatest of these came from a northwesterly direction and fed on the heavy grass of the prairie stretching without interruption all the way from the Boone river to the Skunk river bounding the Story county section.

During high winds the mighty flames would come at race-horse speed, high as a house, and sweeping everything before them. It was a thrilling, awe-inspiring sight. Backfires around the homesteads were resorted to as a means of safety, and unless these burnt areas were about thirty rods wide, there was danger that the flames would leap over in the form of fiery sparks to threaten the life of the pioneer and all his substance. Having measured out the area of safety, the better protection against such perils was 
to plow within this safety-zone several furrows a rod or two apart, and then at the proper time, burn carefully the intervening spaces separately, in view of the fire menace in the fall.

\section{Sometimes From the EAST}

Settlers often were caught unprepared for prairie fires, as was instanced by Haaver Thompson, who was burnt out by a sudden blaze that came up from the east and destroyed all that he had established on his prairie location some seven miles northeast of Story City. There was practically nothing left to move except himself and family, as he pulled out for a more protected location four miles southwest near the brink of a high bluff on the west side of Skunk river. Here he was free from any flames following at his heels up that bare bluff from the east, and toward the northwest he had protection from the timber. Toward the west lay a baby-swamp, south of him was timber and southwest a corridor led to the prairie across slopes and elevations and a cultivated field, natural protections all-or mostly!

The greedy flames sweeping westward among the hills further east did not spare Store Per's seven-year old daughter, who was caught in their furious onrush only a short distance from home and burned to death. Per, though quick of action in emergencies, made every effort humanly possible to save her, but failed. What a trial to be visited upon the parents; what anguish, what sorrow!

\section{The Wilkinson Home Burned}

In one of the greatest conflagrations that vaulted over the prairies from an easterly direction the Schweringen family met death; and the home of the Wilkinson family, some four miles east of Story City, was ravaged. The Civil war veteran, E. C. Wilkinson, a son in the latter family, related that their main wherewithal of subsistence was licked up by the flames, causing them a seemingly hopeless setback. The elder Wilkinson having passed away, the calamity roused 
the remaining ones, especially the seventeen-year old son, to action; he thought of the old adage "Never say die", and determinedly set off to Illinois Grove, some thirty miles east, in the spring for seed wheat. They managed to keep body and soul together in the interim, and by autumn Nature had provided another harvest, and enough grain was flailed out for their modest needs.

The Wilkinsons worked faithfully to rehabilitate themselves, and by the time the Civil war came along young Wilkinson entered the army and was able to leave the much tried family fairly well provided for. Thus, midst ravages of fire and flood, war and other visitations, the pioneers set an excellent example of unyielding effort, applying themselves devotedly, living within their means and caring for their obligations, first requisites to success. And often the heroines of the home showed fortitude fairly equalling the bravery of those called to the colors.

\section{The Schweringen FIRE Victims}

As told by James Brown, the Schweringen family of five, part way on their journey through this section, October 1860, were overtaken by a prairie-firewith fatal result. They were traveling in a prairie schooner drawn by a team of horses, having come from Ohio, and being on their way to Fort Dodge, Iowa, where they had previously entered on 160 acres of land for future occupancy. Here they looked forward to a material abode of comfort and happiness, but this was not to be; they were unexpectedly ushered into another world and never reached their earthly destination.

At Nevada, Iowa, they had rested their horses, taking the opportunity at the same time to lay in a stock of necessary camp supplies. Among other things, they took along a store of lard and cotton, which they hung high under the schooner top for safety. Their domestic concerns take on a tinge of pathos in view of their impending fate. As they left Nevada, a strong 
wind prevailed, and about halfway between that place and Story City they became aware of a fast advancing fiery turmoil, propelled by it and pursuing them from behind. They then were passing through some very heavy grass, and almost before they realized it, they were enveloped by the oncoming blaze which quickly consumed the wagon-cover and roasted their flesh. The horses and all succumbed before it, with the exception of Mr. Schweringen himself, who remained sufficiently alive to make his way in a terrible frenzy of distress to Mr. Hoover's home about a mile distant. Here he was taken in and tenderly cared for by the family and helping neighbors, but in spite of all that friendly hands could do, he soon expired from his burns.

As soon as the scorching heat from the fire had subsided the neighbors went on a quest for the bodies of the unfortunates; and they found the charred remains of Mrs. Schweringen and two of the children, with the third child missing. The remains were placed in a rude box and interred in the Sheffield cemetery. $\mathrm{Mr}$. Schweringen was buried beside his hapless family, when he passed away a few days later. Later, the skull of the missing child was discovered and interred where found. It seemed entirely suitable and highly commendable when a stone was recently placed in the Sheffield cemetery in memory of the Schweringens and their grevious passing.

LOCAL Flare-ups

Local fires were sometimes set by the settlers themselves to clear off patches of weeds or coarse sloughgrass. They were usually set off after dusk and loomed alarmingly large as seen from a distance. It was a real adventure for the pioneer children when they were allowed to go along and view the fiery spectacle, and to light little fires of their own and watch the tiny flame spread and suddenly leap to power. To walk barefoot in the smoking stubble took the hardened sole of many moons to withstand. But what if the toes were stub- 
bed, or the feet bled-what was that to bother about considering all the glorious fun! Sometimes such home fires would take on mischievious antics, and would even get out of control, send devastating feelers around and beyond their proper pale, and cause damage.

One night in the long ago father was awakened by an irate neighbor who demanded to know who had started a fire nearby on the prairie meadow which was now threatening to invest his homestead! It developed that an older brother had found a smoldering buffalo-chip when herding the cattle, had breathed upon it leaving it to smoke. However, it not only smoked, but it flared up! When roused from his dreams for questioning his consternation knew no bounds when he learned that his meddling had resulted in a man-sized blaze, which had spread in the night. Fortunately, no particular harm was caused thereby.

\section{House AND BARN Fires}

Other fires a'plenty were caused by a general lack of watchfulness, such as inattention to stove pipes and chimneys, and from smoker-carelessness with matches, which, also, when gotten hold of, intrigued the children. Their experiments with these sulphur-tinged "sticklets" often turned out very badly. Whatever its origin, whether due to child ingenuity, adult carelessness or other, it is told that when a certain neighbor woman discovered her house was on fire she outdid eventual sirens by yelling so lustily that the neighbors caught on, jumped their horses and came on a dead run to effect rescue, even more promptly, perhaps, than a speedy modern fire truck could have swung into action.

Before the era of the general use of the lightning rod, lightning often caused fires in barns and sheds as well as in dwellings, during electrical storms. At night, after such a storm, the lurid hue from burning buildings, ignited from a lightning bolt, could be seen reflected in the clouds a considerable distance away. A neighbor woman dreaded the sight of lightning so much that she chose to remain in the darkest corner 
in the cellar while the fiery flashes continued. However, a shaft of lightning sought her out in her hiding place and administered a fatal shock. During the most awful play of thunder and lightning certain men's faces would blanch and they would stop swearing, thus tacitly disapproving such unholy habit. Many remained quiet and trustful even during unusually rough weather perceiving the "finger o' God i' this thing," as in other manifestations of Nature. What of the blinding electrical force charging through the atmosphere, which leaves a dazzling path of splendor in its wake, and foments an air disturbance that causes a thunderous roar, outdoing even that heard in the action of an army engagement? The newly arrived immigrants were not used to the mighty play of the elements seen and experienced here, the formidable clouds, the furious wind, the awesome lightning, the deafening thunder, causing them to be greatly dismayed at first.

\section{Early Churches and Schools}

The groundwork for establishment of educational institutions in Iowa was laid before it became a state. The early settlers surged over the Mississippi river into Iowa district following the Blackhawk war in Illinois and Wisconsin and General Scott's purchase for the government of Iowa land from the Indians. They first felt the need and formed the nuclei for religious organizations here. Church missionaries appeared in various localities in settlements along the eastern border in the early thirties and meetings held in cabins of settlers. While Roman Catholic priests were the first to enter the territory, as early as 1834 , the first church of any denomination was established by the Methodists in a cabin erected for that purpose at Dubuque.

A few private schools were conducted in the area as early as 1830, but it was in January, 1841 that the Territorial Legislature passed the act that created the office of superintendent of public instruction. Although 
it was after the territorial organization was effected that a law was passed which defined the means of establishing free public schools, they had been authorized when the area was still a part of both the Territory of Michigan and the Territory of Wisconsin. When Iowa became a territory in 1838 , more than 40 schools had been established.

Before state operated educational institutions had been established, the church organizations maintained elementary and secondary schools and also had founded several schools of higher education. Essential offcial data regarding the establishment of the first college organizations in Iowa is not easily obtainable, as the meager support afforded sometimes occasioned gaps in period of operation; moreover, the changes in names and locations of organizations tends to confuse the records of institutions which really had continuous operation and grew to be valuable components of educational facilities in modern Iowa, rightfully deserving credit for their pioneering in early territorial days.

\section{Farmer's Margin Less}

"The farmer in 1952 found himself being gently, but firmly, squeezed between the vice of stable or mounting costs, and lower prices for his product," says Thomas Clark, a market authority.

The gross income was holding near record levels, but the net was declining. And, both figures were being held up by high production, since actual market prices were off more than income figures indicated.

The result was that the farmer found an even greater premium on efficiency, and the so-called marginal producer was finding it more difficult to keep his head above water.

Last year's net farm income for the nation was estimated at $\$ 14,200,000,000$, down 100 million from the 1951 total, and over 2.5 billion below the record of $\$ 16,774,000,000$ chalked up in 1947. 
Copyright of Annals of Iowa is the property of State of Iowa, by \& through the State Historical Society of Iowa and its content may not be copied or emailed to multiple sites or posted to a listserv without the copyright holder's express written permission. However, users may print, download, or email articles for individual use. 